\title{
Effects of Drip Irrigation on Growth, Physiological Parameters, and Yield in Hydroponically Cultivated Cucumis sativus
}

\author{
Donavon Sonnenberg \\ Department of Horticultural Sciences, Faculty of Applied Sciences, Cape \\ Peninsula University of Technology, Bellville 7535, P.O. Box 1906, Cape \\ Town, Western Cape Province, South Africa
}

Patrick A. Ndakidemi

The Nelson Mandela African Institute of Science and Technology, School of Life Sciences and Bio-engineering, Nelson Mandela Road, P.O. Box 447, Arusha, Tanzania

\section{Ambrose Okem ${ }^{1}$ and Charles Laubscher \\ Department of Horticultural Sciences, Faculty of Applied Sciences, Cape Peninsula University of Technology, Bellville 7535, P.O. Box 1906, Cape Town, Western Cape Province, South Africa}

Additional index words. crop yield, growth parameters, intercellular $\mathrm{CO}_{2}$ concentration, photosynthetic rate, transpiration rate

\begin{abstract}
The effect of drip irrigation regimen on growth, physiological parameters, and crop yield in Cucumis sativus L. was investigated using a drip irrigation system. The experimental design comprised eight various water regimens $(2,4,6,8,10,12,14$, and $\left.16 \mathrm{~L} \cdot \mathrm{h}^{-1}\right)$. Plants received water five times a day, making a total of 10, 20, 30, 40, 50, 60, 70, and $80 \mathrm{~L}$ per day. Growth and photosynthetic parameters were analyzed on a weekly base for a period of 8 weeks. Crop yield was measured at the end of the experiment. In general, photosynthetic rate $(A)$, intercellular $\mathrm{CO}_{2}$ concentration $\left(C_{i}\right)$, stomatal conductance $\left(g_{S}\right)$ and the transpiration rate $(E)$ of the cucumber plants were enhanced by increasing water quantities compared with the control. Overall, the total chlorophyll content was significantly enhanced between week 7 and 8 in plants treated with high irrigation volume. Significant improvements were recorded in plant height and number of leave from week 3 to 8 in plants supplied with high irrigation volume. The observed increase in photosynthetic parameters, chlorophyll contents, and plant growths perhaps accounted for the significant increase in the number of marketable fruits in cucumber grown in higher water regimen. The optimal yield of cucumber in the present study was attained in plants irrigated with water regimen ranging from 40 to $80 \mathrm{~L}$ per day. The results of this study present valuable information that cucumber growers in South Africa should adopt the use of drip irrigation technique to save water considering the high drought condition in the country.
\end{abstract}

One of the major constraints to most vegetables growers in South Africa is related to water management and water use efficiency. This problem has added to the already enormous problem of drought in the country (Sedibe, 2003). Consequently, it is extremely important for growers to know the exact amount of water required for their crops to get exceptional yields of high quality. Achieving this will support vegetable growers in saving extra costs on water and hence increase their profits (Chartzoulakis and Drosos, 1995; Sedibe, 2003).

\footnotetext{
Received for publication 23 June 2016. Accepted for publication 3 Sept. 2016.

We thank the Western Cape Department of Agriculture and Cape Peninsula University of Technology for financial support.

${ }^{1}$ Corresponding author. E-mail: okema@cput.ac. za
}

Drip irrigation is a localized technology that supplies water and dissolved nutrients directly to the roots of crops. This improves photosynthetic capacity of plants, maximizing yield, minimizing water usage, and reducing environmental pollution (Abdelraouf et al., 2013). Unlike other irrigation methods, drip irrigation conserves more water, and provides high levels of uniformities and application efficiencies. A number of studies in various crops have validated the positive effects of drip irrigation in improving crop yields (Ertek et al., 2006; Sezen et al., 2006; Vázquez et al., 2006). The global demand for nutrition is on the increase and the only means to meet such demand is to increase crop yield by improving the photosynthetic efficiency of plants. Plant biomass production is directly dependent on the net photosynthetic rate (Sing et al., 2013). Photosynthesis is the process by which photosynthetically active radiation (within the wavelength range 400 $700 \mathrm{~nm}$ ) is used in the presence of chlorophyll to synthesis carbohydrate such as sugar from $\mathrm{CO}_{2}$ and water (Petela, 2007). Photosynthetic rate $(A)$, intercellular $\mathrm{CO}_{2}$ concentration $\left(\mathrm{C}_{\mathrm{i}}\right)$, $g_{\mathrm{S}}$, transpiration rate (e), and dry matter production of plants are closely linked processes, which are usually influenced by water availability to plant.

Photosynthesis is proportional to $g_{\mathrm{S}}$, which plays a pivotal role in regulating the net $\mathrm{CO}_{2}$ uptake during abiotic stress (Haworth et al., 2011). Elevated $g_{S}$ favor carboxylation efficiency of RubisCO, but can lead to higher rates of water loss and associated risk of desiccation and xylem embolism, in addition to metabolic costs of enhanced construction of stomatal complexes (Cornic, 2000; Haworth et al., 2011).

Water deficiency is one of the most critical abiotic stresses that affect plant physiology and development (Gueta-Dahan et al., 1997). Limited water supply not only reduces chlorophyll content in plants, but also leads to poor growth and subsequently reduce crop yield (Anjum et al., 2003; Begun and Paul, 1993; Mafakheri et al., 2010; Moran et al., 1994; Younis et al., 2000; Zayed and Zeid, 1997). Previous studies have shown that fruit size and yield in crops supplied with adequate amount of water increase significantly compared with crops exposed to limited quantities (Kumar et al., 2007; Mao et al., 2002; Zeng et al., 2009).

Cucumber (C. sativus) is an economically important vegetable that is widely cultivated throughout the world. Cucumber has several nutritional values as functional food, possess high antioxidant properties as well as high mineral content (Chu et al., 2002). Cultivation of cucumbers often suffers setbacks from biotic and abiotic stresses during the whole development life cycle, which lead to reduction in yield and quality. Glasshouse soilless growers have expressed concern that water quantity may be suboptimal for plant growth.

South Africa is faced with extended drought conditions, which pose a big threat to crop growers in the country and there is need to adopt new and effective technology for optimal crop yield and efficient management of the limited available water. Therefore, understanding the optimum water regimen required for the optimum growth of cucumber plants in a drip irrigation system is essential. This study was aimed to investigate the effect of drip irrigation technique on plant growth and physiological parameters as well as crop yield in $C$. sativus under controlled glasshouse conditions.

\section{Materials and Methods}

\section{Site location and description}

This study was carried out during the spring-summer season 2010 in a glasshouse at the Agronomy and Vegetables Department of the Cape Institute for Agricultural Training in Elsenburg, South Africa. The glasshouse was covered with alunet ( $40 \%$ shade screen). and had a fully automated fertigation system. The light condition and photosynthetic photon flux $(P P F)$ of $40-50 \mu \mathrm{mol} \cdot \mathrm{m}^{-2} \cdot \mathrm{s}^{-1}$ provided by cool white fluorescent lamps (Osram L 58W/ 640; Osram, Germany) as measured at the 
plant level. The temperature was maintained at $24 \pm 2{ }^{\circ} \mathrm{C}$ and relative humidity was $66 \%$. The cucumber plantlets were placed in 20 -L black bags consisting of sawdust as a growth medium. The plants were irrigated using drip irrigation and plants were staked with polyethylene twines.

Seeds of C. sativus cv. Alladin, a highyielding cucumber variety were purchased from A. Ford \& Co. (Pty) Ltd., Cape Town, South Africa. These were germinated by Propagating Plants Company (Klein Joostenburg farm, Cape Town, South Africa). Five-day-old seedlings were used in the subsequent experiment.

\section{Experimental design and treatments}

The experimental set-up was a completely randomized block design, including eight water regimens $\left[2 \mathrm{~L} \cdot \mathrm{h}^{-1}\right.$ (control), 4, 6, 8, $10,12,14$, and $\left.16 \mathrm{~L} \cdot \mathrm{h}^{-1}\right]$. The plants received water five times a day as follows: 10, 20,30, $40,50,60,70,80 \mathrm{~L}$ per day. The experiment was set-up on a galvanized steel table $(2 \times 8.5 \mathrm{~m})$. Beneath each table, five $(20 \mathrm{~L})$ reservoirs were used to supply the nutrient solution to each gutter above, for $5 \mathrm{~h}$ per day using an electric timer. Plant nutrients were supplied hydroponically using Hygroponic and Calcium nitrate fertilizer (Omnical ${ }^{\mathrm{TM}}$ ) obtained from Hygrotech Seed (Pty) Ltd, Strand. The trial was in a drain-to-waste system and was conducted over a $60-\mathrm{d}$ period. There were eight replicates per treatments and all the treatments received the same amount of nutrients. The electrical conductivity of the nutrient solution was set at $1.65 \mathrm{mS} \cdot \mathrm{cm}^{-1}$ (Combrink, 2005). All experiments were carried out in an environmentally controlled glasshouse and repeated twice.

\section{Photosynthesis and chlorophyll \\ measurements}

Photosynthesis and other related measurements were taken at 1-8 weeks after planting.
The photosynthetic rate $(\mathrm{A})$, intercellular $\mathrm{CO}_{2}$ concentration $\left(\mathrm{C}_{\mathrm{i}}\right), g_{\mathrm{S}}$, and transpiration rate (E) were measured in young leaves (flag leaf) per treatment using a portable infra-red gas analyzer (LCpro + 1.0 ADC; Bioscientific Ltd., Hoddesdon, Hertfordshire, UK). Measurements were carried out between 8 and $11 \mathrm{Am}$. Leaves were allowed to acclimatize to the light environment in the chamber for $5 \mathrm{~min}$. Under normal conditions, each measurement took $\approx 2$ min, which was the minimum time allowed for the readings to stabilize before they were recorded. During measurements, the conditions in the leaf chamber were: $P P F$ density $=1100$ $\mu \mathrm{mol}$ (quantum) $\mathrm{m}^{-2} \cdot \mathrm{s}^{-1}$, relative humidity $=$ $44 \%$, leaf vapor pressure deficit $=1.83 \mathrm{kPa}$, flow rate $=400 \mu \mathrm{mol} \cdot \mathrm{s}^{-1}$, reference $\mathrm{CO}_{2}=400$ $\mathrm{ppm}$, and leaf temperature $=25^{\circ} \mathrm{C}$.

Chlorophyll pigments were extracted by dimethyl sulfoxide (DMSO) (Hiscox and Israelstam, 1979). Fresh leaf samples $100 \mathrm{mg}$ were placed in a $15-\mathrm{mL}$ vial containing $7 \mathrm{~mL}$ DMSO and incubated at $4{ }^{\circ} \mathrm{C}$ for $72 \mathrm{~h}$. After the incubation period, samples were filtered through Whatman No. 1 filter paper and then diluted to $10 \mathrm{~mL}$ by adding $3 \mathrm{~mL}$ DMSO and the absorbance read at 645 and $663 \mathrm{~nm}$ on a spectrophotometer (ultraviolet/visible spectrophotometer, Pharmacia LKB. Ultrospec II E) against DMSO blank. Pigment content was expressed as $\mu \mathrm{g} \cdot \mathrm{g}^{-1} \mathrm{FW}$. Chlorophyll levels were calculated using the following equations used by Arnon (1949).

$$
\begin{aligned}
& \text { Chl } a=12.7 \mathrm{D}_{663}-2.69 \mathrm{D}_{645} \\
& \mathrm{Chl} b=22.9 \mathrm{D}_{645}-4.68 \mathrm{D}_{663}
\end{aligned}
$$

Total Chl $=20.2 \mathrm{D}_{645}+8.02 \mathrm{D}_{663}$

Plant growth and crop yield measurements. Plant height (aboveground) was measured with the use of a measuring tape on a weekly basis and the number of leaves per plant was also counted. At the end of the experiment, number, diameter, and length of fruits were recorded. On the basis of observations and measurements, fruits were grouped into marketable fruits (length $>18 \mathrm{~cm}$ and diameter $>3 \mathrm{~cm}$ ) and fruits less than values were regarded as nonmarketable fruits. Fruit net weight was recorded. The rind color of the cucumbers fruits was also rated on a scale of $1-5 ; 1=$ least green and $5=$ most green

\section{Statistical analysis}

Data were subjected to statistical analysis by one way analysis of variance using the STATISTICA 2012 software program for Windows (StatSoft Inc., Tulsa, OK). Significant effects were accepted at the $95 \%$ confidence level $(P \leq 0.05)$.

\section{Results}

Effect of drip irrigation on photosynthetic rate in cucumber. The photosynthetic rate significantly increased at week 1 in almost all the treatments, while the lowest were recorded at 6 and $8 \mathrm{~L} \cdot \mathrm{h}^{-1}$ treatments (Table 1 ). There was a high level of fluctuation in the photosynthetic rate from week 2 to 8 . For instance, photosynthetic rate significantly decreased in week 2 in all the treatments (Table 1), and then slightly increased in week 3 in most of the treatments. However, photosynthetic rate significantly decreased further at week 4 in most of the treatments, but slightly increased progressively at week 5 and maintained a similar trend through weeks 6,7 , and 8 , respectively. The least photosynthetic rate was recorded at $12 \mathrm{~L} \cdot \mathrm{h}^{-1}$ in week 7 . High levels of transpiration rate was recorded in week 1 and treatments 10 , 14 , and $16 \mathrm{~L} \cdot \mathrm{h}^{-1}$ water regimens had the highest transpiration rate (Table 2). Application of different water regimens significantly decreased the transpiration rate in week 2 in all

\begin{tabular}{|c|c|c|c|c|c|c|c|c|}
\hline \multirow[b]{2}{*}{ Treatment $\mathrm{L} \cdot \mathrm{h}^{-1}$} & \multicolumn{8}{|c|}{$\mathrm{A}\left(\mu \mathrm{mol} \cdot \mathrm{m}^{-2} \cdot \mathrm{s}^{-1} \mathrm{CO}_{2}\right)$} \\
\hline & Week 1 & Week 2 & Week 3 & Week 4 & Week 5 & Week 6 & Week 7 & Week 8 \\
\hline 2 & $10.20 \pm 1.06 \mathrm{ab}$ & $3.65 \pm 0.36 a$ & $3.96 \pm 0.34 \mathrm{a}$ & $3.97 \pm 0.28 \mathrm{a}$ & $3.17 \pm 0.30 \mathrm{e}$ & $4.06 \pm 0.22 \mathrm{ab}$ & $4.18 \pm 0.42 b$ & $4.51 \pm 0.40 \mathrm{ab}$ \\
\hline 4 & $9.00 \pm 0.76 b c$ & $2.92 \pm 0.28 \mathrm{a}$ & $5.00 \pm 0.61 \mathrm{a}$ & $3.40 \pm 0.36 \mathrm{a}$ & $3.46 \pm 0.23 \mathrm{de}$ & $2.41 \pm 0.37 \mathrm{c}$ & $2.72 \pm 0.39 \mathrm{c}$ & $3.93 \pm 0.38 \mathrm{bc}$ \\
\hline 8 & $7.40 \pm 1.31 \mathrm{~cd}$ & $2.91 \pm 0.17 \mathrm{a}$ & $3.57 \pm 0.32 \mathrm{a}$ & $2.91 \pm 0.24 \mathrm{a}$ & $4.01 \pm 0.26 \mathrm{bcd}$ & $3.41 \pm 0.31 \mathrm{~b}$ & $3.23 \pm 0.39 b c$ & $2.95 \pm 0.16 \mathrm{~d}$ \\
\hline 10 & $11.76 \pm 0.23 \mathrm{a}$ & $3.40 \pm 0.41 \mathrm{a}$ & $4.87 \pm 0.32 \mathrm{a}$ & $2.68 \pm 0.28 \mathrm{a}$ & $4.20 \pm 0.18 \mathrm{ab}$ & $3.59 \pm 0.41 \mathrm{ab}$ & $4.12 \pm 0.48 b$ & $4.79 \pm 0.35 \mathrm{ab}$ \\
\hline 12 & $10.42 \pm 0.86 \mathrm{ab}$ & $2.63 \pm 0.40 \mathrm{a}$ & $3.42 \pm 0.58 \mathrm{a}$ & $2.94 \pm 0.31 \mathrm{a}$ & $4.12 \pm 0.24 \mathrm{abc}$ & $4.00 \pm 0.41 \mathrm{ab}$ & $1.13 \pm 0.01 \mathrm{~d}$ & $3.43 \pm 0.34 \mathrm{~cd}$ \\
\hline 14 & $11.11 \pm 0.57 \mathrm{ab}$ & $3.89 \pm 0.34 a$ & $4.86 \pm 0.71 \mathrm{a}$ & $2.91 \pm 0.41 \mathrm{a}$ & $4.18 \pm 0.23 \mathrm{ab}$ & $3.49 \pm 0.15 \mathrm{ab}$ & $5.78 \pm 0.29 a$ & $4.59 \pm 0.33 \mathrm{ab}$ \\
\hline
\end{tabular}

Table 1. Effect of drip irrigation on photosynthetic rate (A) between weeks 1 and 8 in Cucumis sativus.

Values (mean $\pm \mathrm{SE}, \mathrm{n}=10$ ) followed by dissimilar letters in a column are significantly different at $P \leq 0.05$.

\begin{tabular}{|c|c|c|c|c|c|c|c|c|}
\hline \multirow[b]{2}{*}{ Treatment $\mathrm{L} \cdot \mathrm{h}^{-1}$} & \multicolumn{8}{|c|}{$\mathrm{E}\left(\mathrm{mmol} \mathrm{m} \mathrm{m}^{-2} \cdot \mathrm{s}^{-1}\right)$} \\
\hline & Week 1 & Week 2 & Week 3 & Week 4 & Week 5 & Week 6 & Week 7 & Week 8 \\
\hline 2 & $1.24 \pm 0.12 \mathrm{~d}$ & $0.92 \pm 0.12 \mathrm{c}$ & $0.90 \pm 0.06 \mathrm{~cd}$ & $0.76 \pm 0.10 \mathrm{~cd}$ & $0.73 \pm 0.05 \mathrm{~d}$ & $1.01 \pm 0.08 \mathrm{ab}$ & $1.14 \pm 0.03 \mathrm{de}$ & $1.00 \pm 0.07 \mathrm{~cd}$ \\
\hline 4 & $1.88 \pm 0.14 \mathrm{bc}$ & $1.38 \pm 0.11 \mathrm{ab}$ & $1.22 \pm 0.09 \mathrm{~b}$ & $1.17 \pm 0.14 \mathrm{a}$ & $1.31 \pm 0.10 \mathrm{ab}$ & $1.17 \pm 0.09 \mathrm{a}$ & $1.03 \pm 0.10 \mathrm{e}$ & $1.29 \pm 0.07 \mathrm{ab}$ \\
\hline 6 & $1.87 \pm 0.12 \mathrm{bc}$ & $1.15 \pm 0.11 \mathrm{bc}$ & $1.16 \pm 0.10 \mathrm{~b}$ & $0.96 \pm 0.13 \mathrm{ab}$ & $1.23 \pm 0.07 \mathrm{ab}$ & $1.08 \pm 0.09 \mathrm{ab}$ & $1.15 \pm 0.08 \mathrm{de}$ & $1.15 \pm 0.08 \mathrm{bc}$ \\
\hline 8 & $1.65 \pm 0.17 \mathrm{c}$ & $1.26 \pm 0.17 \mathrm{~b}$ & $1.09 \pm 0.07 \mathrm{bc}$ & $0.92 \pm 0.09 \mathrm{abc}$ & $1.29 \pm 0.12 \mathrm{ab}$ & $1.13 \pm 0.08 \mathrm{ab}$ & $1.27 \pm 0.12 \mathrm{bcd}$ & $1.39 \pm 0.07 \mathrm{a}$ \\
\hline 10 & $2.19 \pm 0.02 \mathrm{ab}$ & $1.42 \pm 0.11 \mathrm{ab}$ & $1.43 \pm 0.09 \mathrm{a}$ & $0.98 \pm 0.09 \mathrm{ab}$ & $1.33 \pm 0.03 \mathrm{a}$ & $0.75 \pm 0.11 \mathrm{c}$ & $1.19 \pm 0.07 \mathrm{cde}$ & $1.23 \pm 0.03 \mathrm{ab}$ \\
\hline 12 & $1.81 \pm 0.10 \mathrm{c}$ & $1.38 \pm 0.08 \mathrm{ab}$ & $1.14 \pm 0.04 \mathrm{~b}$ & $0.66 \pm 0.06 \mathrm{~d}$ & $1.15 \pm 0.05 \mathrm{ab}$ & $0.97 \pm 0.09 \mathrm{abc}$ & $1.42 \pm 0.08 \mathrm{abc}$ & $0.94 \pm 0.04 \mathrm{~d}$ \\
\hline 14 & $2.49 \pm 0.08 \mathrm{a}$ & $1.65 \pm 0.06 \mathrm{a}$ & $1.16 \pm 0.06 \mathrm{~b}$ & $1.03 \pm 0.06 \mathrm{ab}$ & $1.12 \pm 0.05 \mathrm{bc}$ & $0.91 \pm 0.06 \mathrm{bc}$ & $1.43 \pm 0.06 \mathrm{ab}$ & $1.13 \pm 0.05 b c$ \\
\hline 16 & $2.20 \pm 0.09 \mathrm{a}$ & $1.32 \pm 0.07 \mathrm{~b}$ & $0.86 \pm 0.06 \mathrm{~d}$ & $0.75 \pm 0.07 \mathrm{~cd}$ & $0.92 \pm 0.04 \mathrm{~cd}$ & $1.04 \pm 0.05 \mathrm{ab}$ & $1.61 \pm 0.08 \mathrm{a}$ & $1.17 \pm 0.04 \mathrm{~b}$ \\
\hline
\end{tabular}

Table 2. Effects of drip irrigation on the transpiration rate (E) between weeks 1 and 8 in Cucumis sativus.

Values (mean $\pm \mathrm{sE}, \mathrm{n}=10$ ) followed by dissimilar letters in a column are significantly different at $P \leq 0.05$. 
the treatments (Table 2). The lowest rate of transpiration was recorded in most of the treatments in week 4. Transpiration rate increased slightly in week 5 then decreased in week 6 , it slightly increased in 7 and there was a negligible change in week 8 . The amounts of $\mathrm{Ci}$ significantly increased from week 1 to 2 in almost all the treatments except at $6 \mathrm{~L} \cdot \mathrm{h}^{-1}$ treatments where there was a decrease in $\mathrm{Ci}$ (Table 3). The water regimens at 12 and $14 \mathrm{~L} \cdot \mathrm{h}^{-1}$ increased the concentrations of $\mathrm{Ci}$ slightly in week 3 but decreased in week 4 (Table 3). Extended irrigation increased the $\mathrm{Ci}$ in week 8 in all the treatments which was significantly higher than week 1 (Table 3 ). The fluctuations in $g_{\mathrm{S}}$ in all the treatments followed similar trends in the transpiration rate. For instance, a progressive decrease in $g_{\mathrm{S}}$ was recorded in all the treatments from week 1 to 4 (Table 4). Water regimen at $14-16 \mathrm{~L} \cdot \mathrm{h}^{-1}$ in week 8 slightly improved the $g_{\mathrm{S}}$ compared with the control.

Effect of drip irrigation on foliage color and chlorophyll content in cucumber. Application of water regimen in all the treatments significantly enhanced the foliage color compared with the control in week 3 except at $4 \mathrm{~L} \cdot \mathrm{h}^{-1}$ treatment (Table 5). The best foliage color was recorded in week 7 in plants treated with $8-16 \mathrm{~L} \cdot \mathrm{h}^{-1}$ water regimens compared with the control.

There was a slight increase in the amounts of total chlorophyll content at week 2 in plants treated with $10-16 \mathrm{~L} \cdot \mathrm{h}^{-1}$ water regimens compared with the control (Table 6). There was a decrease in chlorophyll contents in all the treatments from week 3 to 5 . A progressive increase in chlorophyll content was recorded from week 7 to 8 . The highest amounts of total chlorophyll was recorded at week 8 in all the treated plants compared with the control.

Effect of drip irrigation on plant growth and crop yield in cucumber. A progressive increase in plant height was recorded with increase in irrigation volume from week 1 to 8 compared with the control (Table 7). The best result in terms of plant height was recorded between week 7 and 8 in $12-16 \mathrm{~L} \cdot \mathrm{h}^{-1}$ treatments compared with the control. The number of leaves per plant significantly increased with increase in water regimens and this was in a progressive pattern from week 1 to 7 (Table 8). The highest number of leaves were recorded at week 7 in plants supplied with water quantities ranging from 12 to $16 \mathrm{~L} \cdot \mathrm{h}^{-1}$. At week 8 , there was a slight decrease in number of leaves in all the treatments.

Crop yield significantly improved with increase in the amounts of irrigation volume. In comparison with the control, all the treatments had a significantly higher fruit size (length and width) in a dose-dependent pattern (Table 9). Plants supplied with higher amounts of water had healthy-looking fruits compared with the control. The number of marketable fruits as well as the net fruit weight increased significantly in plants supplied with water regimens ranging from 8 to $16 \mathrm{~L} \cdot \mathrm{h}^{-1}$ compared with the control.

\section{Discussion}

Significant improvement in some of the photosynthetic parameters was recorded with increase in the amount of water using a drip irrigation technology. Drip irrigation technique is an efficient water saving technology and can significantly improve crop yield (Castellanos et al., 2013; Silber et al., 2013). Studies have shown that one of the ways to improve crop yield is to improve photosynthetic rate (Kruger and Volin, 2006). However, a number of contrary literature suggest that photosynthetic rate have little or no effects on crop yield (Reynolds et al., 2000; Richards, 2000). In the present study, the net photosynthetic rate and transpiration were significantly higher in high water irrigation regimens than in low water regimens at week 1 , but decreased progressively until the end of the experiment. The fluctuation in photosynthetic rate between weeks observed in the present study could be an adaptive mechanism of cucumber plants to high water regimen or a possible reallocation of resources to enhance crop yield. The observed fluctuation in photosynthetic rate suggests that cucumber have intrinsic photosynthetic capacity for adaptation. The high levels of oscillation in transpiration rate could possibly affect the turgor. Inhibition of turgor leads to closure of stomatal aperture and this affects plant water status depending on atmospheric evaporative demand (Silber et al., 2013). This phenomenon was reported in an earlier study, where stomatal functioning was greatly reduced as a result of water conditions (Cornic and Briantais, 1991; Leopald, 1964). The significant decrease in $g_{\mathrm{S}}$ suggests that stomatal closure was one of the most important factors contributing to the decrease in photosynthetic rate. Leaf stomata provide entryway for $\mathrm{CO}_{2}$ assimilation in photosynthetic carbon fixation, while preventing rapid dehydration (Blanco et al., 2008).

Plants grown in field experiments respond differently to treatments due to several environmental factors including physicochemical properties of the soil compared with hydroponically grown plants. The present study was carried out in environmentally controlled system hence, seasonal variations or environmental factors had little or no influence on the outcome of the experiment. In our study, soilless hydroponic system was used and the optimal yield of cucumber was obtained at the high water regimens ranging from 8 to $16 \mathrm{~L} \cdot \mathrm{h}^{-1}$. South Africa is faced with severe drought conditions making the cultivation of vegetables a mammoth task due to their high water demand. It is advisable for cucumber growers in South Africa to adopt hydroponic techniques using drip irrigation system to curb the problem of drought in the country as well as effective management of available water.

Intensively managed drip irrigation systems, in which a crop is irrigated frequently, have been proposed as a tool to increase water and nutrient uptake efficiency (Schumann et al., 2009). The high irrigation volume used in this study, perhaps, had a substantial effect in solubilizing the nutrients for optimal uptake by plant. Availability

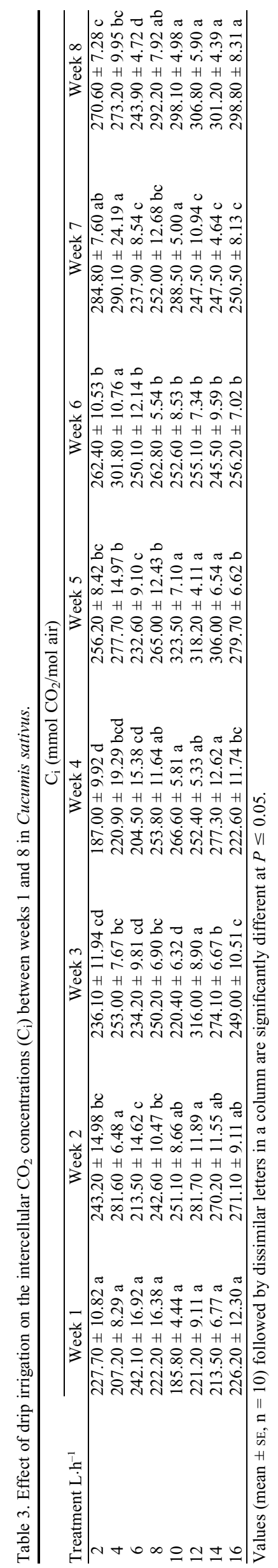


Table 4. Effect of drip irrigation on stomatal conductance $\left(g_{\mathrm{S}}\right)$ between weeks 1 and 8 in Cucumis sativus.

\begin{tabular}{|c|c|c|c|c|c|c|c|c|}
\hline \multirow[b]{2}{*}{ Treatment $\mathrm{L} \cdot \mathrm{h}^{-1}$} & \multicolumn{8}{|c|}{$g_{\mathrm{S}}\left(\mathrm{mmol} \cdot \mathrm{m}^{-2} \cdot \mathrm{s}^{-1} \mathrm{H}_{2} \mathrm{O}\right)$} \\
\hline & Week 1 & Week 2 & Week 3 & Week 4 & Week 5 & Week 6 & Week 7 & Week 8 \\
\hline 2 & $0.15 \pm 0.02 \mathrm{a}$ & $0.06 \pm 0.01 \mathrm{ab}$ & $0.07 \pm 0.01 \mathrm{~cd}$ & $0.12 \pm 0.08 \mathrm{a}$ & $0.05 \pm 0.00 \mathrm{~d}$ & $0.10 \pm 0.02 \mathrm{a}$ & $0.10 \pm 0.01 \mathrm{c}$ & $0.10 \pm 0.01 \mathrm{bc}$ \\
\hline 4 & $0.15 \pm 0.01 \mathrm{a}$ & $0.07 \pm 0.01 \mathrm{a}$ & $0.09 \pm 0.01 \mathrm{~b}$ & $0.06 \pm 0.01 \mathrm{a}$ & $0.08 \pm 0.02 \mathrm{c}$ & $0.08 \pm 0.01 \mathrm{ab}$ & $0.06 \pm 0.01 \mathrm{~d}$ & $0.09 \pm 0.01 \mathrm{~cd}$ \\
\hline 6 & $0.11 \pm 0.01 \mathrm{a}$ & $0.05 \pm 0.01 \mathrm{~b}$ & $0.06 \pm 0.01 \mathrm{~d}$ & $0.03 \pm 0.01 \mathrm{a}$ & $0.05 \pm 0.00 \mathrm{~d}$ & $0.06 \pm 0.01 \mathrm{~b}$ & $0.06 \pm 0.01 \mathrm{~d}$ & $0.07 \pm 0.01 \mathrm{~d}$ \\
\hline 8 & $0.17 \pm 0.04 \mathrm{a}$ & $0.05 \pm 0.01 \mathrm{~b}$ & $0.06 \pm 0.01 \mathrm{~cd}$ & $0.05 \pm 0.01 \mathrm{a}$ & $0.06 \pm 0.01 \mathrm{~d}$ & $0.06 \pm 0.01 \mathrm{~b}$ & $0.06 \pm 0.01 \mathrm{~d}$ & $0.08 \pm 0.01 \mathrm{~cd}$ \\
\hline 10 & $0.16 \pm 0.01 \mathrm{a}$ & $0.06 \pm 0.00 \mathrm{ab}$ & $0.07 \pm 0.01 \mathrm{~cd}$ & $0.05 \pm 0.01 \mathrm{a}$ & $0.17 \pm 0.01 \mathrm{a}$ & $0.06 \pm 0.01 \mathrm{~b}$ & $0.12 \pm 0.01 \mathrm{abc}$ & $0.15 \pm 0.01 \mathrm{a}$ \\
\hline 12 & $0.19 \pm 0.02 \mathrm{a}$ & $0.06 \pm 0.01 \mathrm{ab}$ & $0.13 \pm 0.01 \mathrm{a}$ & $0.05 \pm 0.01 \mathrm{a}$ & $0.13 \pm 0.01 \mathrm{~b}$ & $0.08 \pm 0.01 \mathrm{ab}$ & $0.13 \pm 0.01 \mathrm{ab}$ & $0.12 \pm 0.01 \mathrm{~b}$ \\
\hline 14 & $0.20 \pm 0.01 \mathrm{a}$ & $0.07 \pm 0.00 \mathrm{a}$ & $0.08 \pm 0.01 \mathrm{bc}$ & $0.07 \pm 0.01 \mathrm{a}$ & $0.13 \pm 0.01 \mathrm{~b}$ & $0.06 \pm 0.00 \mathrm{~b}$ & $0.11 \pm 0.01 \mathrm{bc}$ & $0.15 \pm 0.01 \mathrm{a}$ \\
\hline 16 & $0.18 \pm 0.02 \mathrm{a}$ & $0.07 \pm 0.00 \mathrm{a}$ & $0.06 \pm 0.01 \mathrm{~d}$ & $0.05 \pm 0.01 \mathrm{a}$ & $0.12 \pm 0.01 \mathrm{~b}$ & $0.07 \pm 0.01 \mathrm{~b}$ & $0.14 \pm 0.01 \mathrm{a}$ & $0.18 \pm 0.01 \mathrm{a}$ \\
\hline
\end{tabular}

Values (mean \pm sE, $\mathrm{n}=10$ ) followed by dissimilar letters in a column are significantly different at $P \leq 0.05$.

Table 5. Effect of drip irrigation on foliage color of Cucumis sativus between weeks 1 and 8.

\begin{tabular}{|c|c|c|c|c|c|c|c|c|}
\hline \multirow[b]{3}{*}{ Treatment $\mathrm{L} \cdot \mathrm{h}^{-1}$} & \multicolumn{8}{|c|}{ Foilage color (scale from 1 to 5 ) } \\
\hline & \multicolumn{8}{|c|}{ Weeks } \\
\hline & 1 & 2 & 3 & 4 & 5 & 6 & 7 & 8 \\
\hline 2 & $3.75 \pm 0.10 \mathrm{a}$ & $3.75 \pm 0.10 \mathrm{bc}$ & $3.15 \pm 0.15 \mathrm{~d}$ & $3.45 \pm 0.14 \mathrm{bc}$ & $3.40 \pm 0.17 b c$ & $3.05 \pm 0.15 \mathrm{~d}$ & $3.00 \pm 0.10 \mathrm{~d}$ & $3.50 \pm 0.11 \mathrm{c}$ \\
\hline 4 & $3.85 \pm 0.08 \mathrm{a}$ & $3.25 \pm 0.12 \mathrm{~d}$ & $3.30 \pm 0.18 \mathrm{~cd}$ & $3.30 \pm 0.16 \mathrm{c}$ & $3.30 \pm 0.15 \mathrm{c}$ & $3.05 \pm 0.17 \mathrm{~d}$ & $3.60 \pm 0.18 \mathrm{c}$ & $3.90 \pm 0.07 \mathrm{~b}$ \\
\hline 6 & $4.00 \pm 0.00 \mathrm{a}$ & $3.75 \pm 0.10 b c$ & $3.80 \pm 0.14 \mathrm{ab}$ & $4.00 \pm 0.10 \mathrm{a}$ & $3.75 \pm 0.20 \mathrm{abc}$ & $3.65 \pm 0.17 b c$ & $3.95 \pm 0.18 \mathrm{bc}$ & $3.90 \pm 0.07 b$ \\
\hline 8 & $3.90 \pm 0.07 \mathrm{a}$ & $3.55 \pm 0.15 \mathrm{~cd}$ & $3.65 \pm 0.20 \mathrm{bc}$ & $3.75 \pm 0.18 \mathrm{ab}$ & $3.85 \pm 0.18 \mathrm{ab}$ & $3.25 \pm 0.18 \mathrm{~cd}$ & $4.25 \pm 0.16 b$ & $3.85 \pm 0.08 b$ \\
\hline 10 & $3.80 \pm 0.09 \mathrm{a}$ & $4.10 \pm 0.10 \mathrm{a}$ & $3.60 \pm 0.13 b c$ & $3.65 \pm 0.15 \mathrm{abc}$ & $3.75 \pm 0.18 \mathrm{abc}$ & $4.05 \pm 0.15 \mathrm{ab}$ & $4.70 \pm 0.13 \mathrm{a}$ & $4.20 \pm 0.12 \mathrm{a}$ \\
\hline 12 & $3.85 \pm 0.08 \mathrm{a}$ & $3.70 \pm 0.11 b c$ & $3.85 \pm 0.13 \mathrm{ab}$ & $3.70 \pm 0.13 \mathrm{ab}$ & $3.85 \pm 0.18 \mathrm{ab}$ & $4.15 \pm 0.17 \mathrm{a}$ & $4.85 \pm 0.08 \mathrm{a}$ & $3.75 \pm 0.12 b c$ \\
\hline 14 & $3.85 \pm 0.08 \mathrm{a}$ & $3.95 \pm 0.09 \mathrm{ab}$ & $4.10 \pm 0.12 \mathrm{a}$ & $3.85 \pm 0.13 \mathrm{a}$ & $4.15 \pm 0.17 \mathrm{a}$ & $3.95 \pm 0.14 \mathrm{ab}$ & $4.80 \pm 0.09 \mathrm{a}$ & $4.35 \pm 0.11 \mathrm{a}$ \\
\hline 16 & $3.95 \pm 0.09 \mathrm{a}$ & $3.85 \pm 0.08 \mathrm{abc}$ & $4.10 \pm 0.14 \mathrm{a}$ & $3.90 \pm 0.14 \mathrm{a}$ & $4.00 \pm 0.19 \mathrm{a}$ & $4.20 \pm 0.14 \mathrm{a}$ & $4.85 \pm 0.11 \mathrm{a}$ & $4.45 \pm 0.14 \mathrm{a}$ \\
\hline
\end{tabular}

Values (mean $\pm \mathrm{sE}, \mathrm{n}=10$ ) followed by dissimilar letters in a column are significantly different at $P \leq 0.05$

Table 6. Effect of drip irrigation on the chlorophyll content Cucumis sativus between weeks 1 and 8.

\begin{tabular}{|c|c|c|c|c|c|c|c|c|}
\hline \multirow[b]{3}{*}{ Treatment $\mathrm{L} \cdot \mathrm{h}^{-1}$} & \multicolumn{8}{|c|}{ Chlorophyll } \\
\hline & \multicolumn{8}{|c|}{ Weeks } \\
\hline & 1 & 2 & 3 & 4 & 5 & 6 & 7 & 8 \\
\hline 2 & $46.12 \pm 1.54 \mathrm{a}$ & $47.37 \pm 2.22 \mathrm{~d}$ & $50.41 \pm 0.81 \mathrm{~b}$ & $49.59 \pm 0.85 \mathrm{a}$ & $50.81 \pm 1.42 \mathrm{a}$ & $52.21 \pm 1.59 \mathrm{a}$ & $54.02 \pm 1.87 \mathrm{bcd}$ & $52.63 \pm 1.40 \mathrm{c}$ \\
\hline 4 & $50.48 \pm 1.56 \mathrm{a}$ & $51.37 \pm 2.48 \mathrm{~cd}$ & $50.98 \pm 0.78 b$ & $48.56 \pm 0.88 \mathrm{a}$ & $50.80 \pm 1.79 \mathrm{a}$ & $53.77 \pm 1.89 \mathrm{a}$ & $51.71 \pm 1.71 \mathrm{~d}$ & $63.88 \pm 3.38 \mathrm{a}$ \\
\hline 6 & $51.81 \pm 2.84 \mathrm{a}$ & $51.54 \pm 1.79 \mathrm{bcd}$ & $51.30 \pm 0.96 \mathrm{~b}$ & $49.83 \pm 1.04 \mathrm{a}$ & $51.88 \pm 0.90 \mathrm{a}$ & $54.63 \pm 0.94 \mathrm{a}$ & $52.73 \pm 1.46 \mathrm{~cd}$ & $60.50 \pm 1.87 \mathrm{ab}$ \\
\hline 8 & $51.46 \pm 1.73 \mathrm{a}$ & $51.99 \pm 0.73 \mathrm{bc}$ & $50.06 \pm 0.64 b$ & $49.35 \pm 0.74 \mathrm{a}$ & $52.66 \pm 1.14 \mathrm{a}$ & $55.75 \pm 1.71 \mathrm{a}$ & $56.73 \pm 1.77 \mathrm{abc}$ & $61.19 \pm 2.32 \mathrm{ab}$ \\
\hline 10 & $52.26 \pm 0.75 \mathrm{a}$ & $56.65 \pm 1.39 \mathrm{a}$ & $55.33 \pm 0.82 \mathrm{a}$ & $51.78 \pm 1.30 \mathrm{a}$ & $53.35 \pm 1.27 \mathrm{a}$ & $52.94 \pm 1.62 \mathrm{a}$ & $56.97 \pm 1.05 \mathrm{ab}$ & $63.32 \pm 2.60 \mathrm{a}$ \\
\hline 12 & $53.05 \pm 1.14 \mathrm{a}$ & $55.12 \pm 1.09 \mathrm{abc}$ & $51.81 \pm 1.05 \mathrm{~b}$ & $48.70 \pm 1.48 \mathrm{a}$ & $51.93 \pm 1.32 \mathrm{a}$ & $57.54 \pm 2.02 \mathrm{a}$ & $56.45 \pm 1.28 \mathrm{abc}$ & $60.78 \pm 1.69 \mathrm{ab}$ \\
\hline 14 & $52.77 \pm 1.05 \mathrm{a}$ & $57.10 \pm 1.41 \mathrm{a}$ & $56.56 \pm 1.05 \mathrm{a}$ & $53.40 \pm 1.57 \mathrm{a}$ & $54.44 \pm 1.13 \mathrm{a}$ & $57.87 \pm 1.59 \mathrm{a}$ & $58.20 \pm 1.30 \mathrm{a}$ & $55.54 \pm 1.72 b c$ \\
\hline 16 & $50.56 \pm 1.22 \mathrm{a}$ & $55.99 \pm 0.92 \mathrm{ab}$ & $54.82 \pm 1.40 \mathrm{a}$ & $50.98 \pm 1.71 \mathrm{a}$ & $53.15 \pm 0.78 \mathrm{a}$ & $56.35 \pm 1.58 \mathrm{a}$ & $60.14 \pm 0.92 \mathrm{a}$ & $63.90 \pm 1.48 \mathrm{a}$ \\
\hline
\end{tabular}

Values (mean $\pm \mathrm{SE}, \mathrm{n}=10$ ) followed by dissimilar letters in a column are significantly different at $P \leq 0.05$.

Table 7. Effect of drip irrigation on plant growth of Cucumis sativus between weeks 1 and 8 .

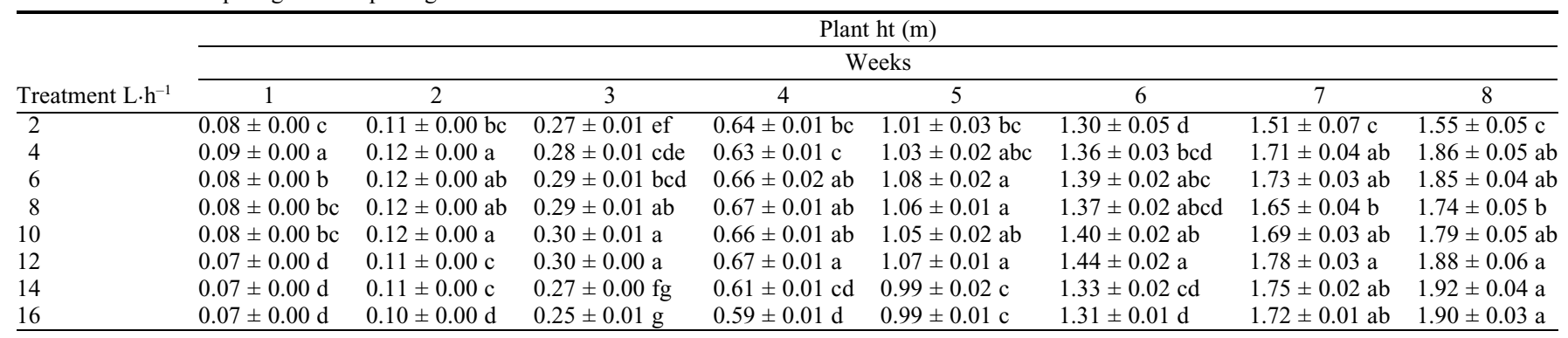

Values (mean $\pm \mathrm{SE}, \mathrm{n}=10$ ) followed by dissimilar letters in a column are significantly different at $P \leq 0.05$.

Table 8. Effect of different drip irrigation on leaf numbers of Cucumis sativus between weeks 1 and 8.

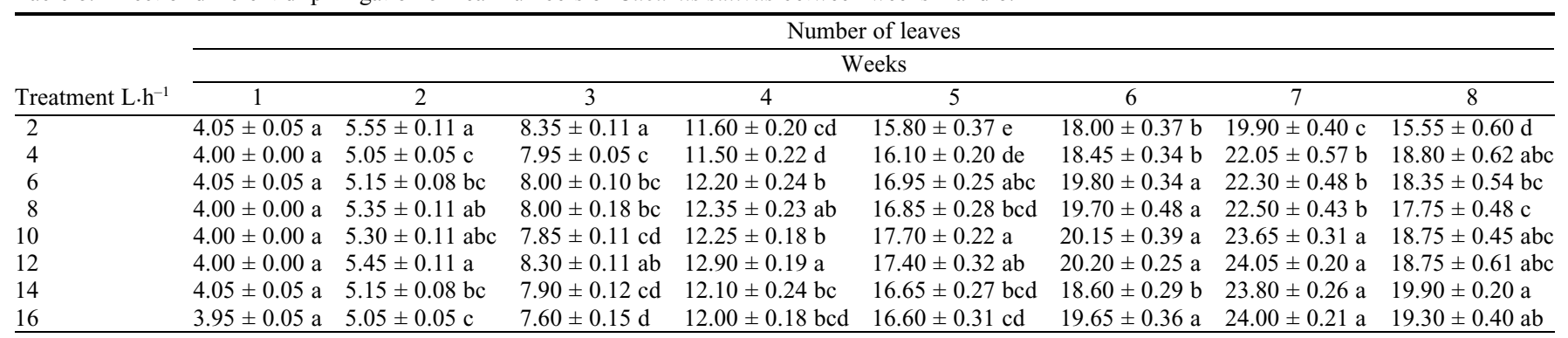

Values (mean $\pm \mathrm{SE}, \mathrm{n}=10$ ) followed by dissimilar letters in a column are significantly different at $P \leq 0.05$. 
Table 9. Effect of different water regime on fruit yield of Cucumis sativus as measured at 8 weeks

\begin{tabular}{lllll}
\hline & \multicolumn{4}{c}{ Week 8} \\
\cline { 2 - 5 } Treatment $\mathrm{L} \cdot \mathrm{h}^{-1}$ & Fruit length $(\mathrm{cm})$ & \multicolumn{4}{c}{ Rind color } & Marketable fruit & Wt $(\mathrm{g})$ \\
\hline 2 & $24.78 \pm 3.74 \mathrm{c}$ & $2.60 \pm 0.31 \mathrm{~d}$ & $1.00 \pm 0.23 \mathrm{~d}$ & $0.90 \pm 0.15 \mathrm{~d}$ \\
4 & $36.47 \pm 0.54 \mathrm{~b}$ & $3.45 \pm 0.23 \mathrm{c}$ & $2.35 \pm 0.25 \mathrm{ab}$ & $1.75 \pm 0.15 \mathrm{a}$ \\
6 & $38.17 \pm 0.61 \mathrm{ab}$ & $3.45 \pm 0.22 \mathrm{c}$ & $1.70 \pm 0.18 \mathrm{c}$ & $1.04 \pm 0.08 \mathrm{~cd}$ \\
8 & $39.48 \pm 0.46 \mathrm{ab}$ & $3.50 \pm 0.14 \mathrm{bc}$ & $2.25 \pm 0.16 \mathrm{bc}$ & $1.31 \pm 0.08 \mathrm{bc}$ \\
10 & $39.88 \pm 0.76 \mathrm{ab}$ & $3.75 \pm 0.10 \mathrm{abc}$ & $2.70 \pm 0.26 \mathrm{ab}$ & $1.58 \pm 0.13 \mathrm{ab}$ \\
12 & $40.08 \pm 0.37 \mathrm{ab}$ & $3.85 \pm 0.08 \mathrm{abc}$ & $2.30 \pm 0.16 \mathrm{~b}$ & $1.42 \pm 0.13 \mathrm{ab}$ \\
14 & $40.08 \pm 0.61 \mathrm{ab}$ & $4.00 \pm 0.15 \mathrm{ab}$ & $2.25 \pm 0.18 \mathrm{bc}$ & $1.34 \pm 0.10 \mathrm{bc}$ \\
16 & $42.15 \pm 0.67 \mathrm{a}$ & $4.20 \pm 0.09 \mathrm{a}$ & $2.90 \pm 0.23 \mathrm{a}$ & $1.76 \pm 0.12 \mathrm{a}$ \\
\hline
\end{tabular}

Values (mean $\pm \mathrm{SE}, \mathrm{n}=10$ ) followed by dissimilar letters in a column are significantly different at $P \leq 0.05$.

of nutrients to plants enhances growth efficiency and this could be the possible explanation for cucumber plants grown at higher water regimens to have more foliage green color in comparison with the control. Foliage greener color is an indication of the chlorophyll content in crops. Plants with greener leaves were found to have more chlorophyll content than the less green plants. The total chlorophyll content was enhanced in plants irrigated with high amounts of water compared with those irrigated with limited water. This is consistent with the results on photosynthetic rate, where plants irrigated with high volumes of water had more photosynthetic activity compared with plants grown in low water regimens. Enhancing the chlorophyll content in plants improve crop yield. Leaf chlorophyll content is one of the most important factors in determining the photosynthetic rate and dry matter production (Dai et al., 2009). Sezen et al. (2006) reported significant improvement in crop yield of bell pepper grown under drip irrigation regimens. In the present study, high irrigation regimens improved crop yield significantly despite the fluctuation in some of the photosynthetic parameters. These perhaps accounted for the significant increase in the number of marketable fruits in plants grown in higher water regimen. There is a likelihood that cucumber plants in this experiment tend to invest more energy in biomass accumulation and fruit yield by remobilization of resources during maturity.

\section{Conclusion}

Notable increases in some of the physiological parameters such as photosynthetic rate, intercellular $\mathrm{CO}_{2}$ concentration, and chlorophyll content in C. sativus could possibly be the reason for improved crop yield. It was observed that at high amounts of irrigation, growth parameters were enhanced and the number of marketable cucumber fruits where significantly increased. Drip irrigation technique has been used to achieve considerable water savings and increases in crop yield. The results of this study present valuable information that cucumber growers in South Africa should adopt the use of drip irrigation technique to save water considering the high drought condition in the country. The results of the present study suggest that a good yield of cucumber crop can be attained within 8 weeks using a hydroponic production system.

\section{Literature Cited}

Abdelraouf, R.E., S.F. El Habbasha, M.H. Taha, and K.M. Refaie. 2013. Effect of irrigation water requirements and fertigation levels on growth, yield and water use efficiency in wheat. Middle-East J. Scientific Res. 16:441-450.

Anjum, F., M. Yaseen, E. Rasool, A. Wahid, and S. Anjum. 2003. Water stress in barley (Hordeum vulgare L.) II. Effect on chemical composition and chlorophyll contents. Pak. J. Agr. Sci. 40:45-49.

Arnon, D.I. 1949. Copper enzymes in isolated chloroplasts, polyphenoxidase in beta vulgaris. Plant Physiol. 24:1-15.

Begun, F.A. and N.K. Paul. 1993. Influence of soil moisture on growth, water use and yield of mustard. J. Agron. Crop Sci. 170:136-141.

Blanco, M.J.S., S. Álvarez, A. Navarro, and S Bañón. 2008. Changes in leaf water relations, gas exchange growth and flowering quality in potted geranium plants irrigated with different water regimens. J. Plant Physiol. 166:468-475.

Castellanos, M.T., A.M. Tarquis, F. Ribas, M.J. Cabello, A. Arce, and M.C. Cartagena. 2013. Nitrogen fertigation: An integrated agronomic and environmental study. Agr. Water Mgt. 120:46-55.

Chartzoulakis, K. and N. Drosos. 1995. Water use and yield of greenhouse grown eggplant under drip irrigation. Agr. Water Mgt. 28:113-120.

Chu, Y.F., J. Sun, X.Z. Wu, and R.H. Liu. 2002. Antioxidant and anti-proliferative activities of common vegetables. J. Agr. Food Chem. 50:6910-6916.

Combrink, N.J.J. 2005. Nutrient solutions and greenhouse management. Combrink Family Trust, Stellenbosch, South Africa.

Cornic, G. 2000. Drought stress inhibits photosynthesis by decreasing stomatal aperture-not by affecting ATP synthesis. Trends Plant Sci. $5: 187-188$.

Cornic, G. and J.M. Briantais. 1991. Partitioning of photosynthetic electron flow between $\mathrm{CO}_{2}$ and $\mathrm{O}_{2}$ reduction in a $\mathrm{C} 3$ leaf (Phaseolus vulgaris L.) at different $\mathrm{CO}_{2}$ concentrations and during drought stress. Planta 183:178-184.

Dai, Y.J., Z.G. Shen, Y. Liu, L.L. Wang, D. Hannaway, and H.F. Lu. 2009. Effects of shade treatments on the photosynthetic capacity, chlorophyll fluorescence, and chlorophyll content of Tetrastigma hemsleyanum Diels et Gilg. Environ. Exp. Bot. 65:177-182.

Ertek, A., S. Sensoy, I. Gedik, and C. Kücükyumuk 2006. Irrigation scheduling based on pan evaporation values for cucumber (Cucumis sativus $\mathrm{L}$.) grown under field conditions. Agr. Water Mgt. 81:159-172.

Gueta-Dahan, Y., Z. Yaniv, B.A. Zilinskas, and G. Ben-Hayyim. 1997. Salt and oxidative stress: Similar and specific responses and their relation to salt tolerance in citrus. Planta 203:460-469.
Haworth, M., C. Elliott-Kingston, and J.C. McElwain. 2011. Stomatal control as a driver of plant evolution. J. Expt. Bot. 62:2419-2423.

Hiscox, J.D. and G.F. Israelstam. 1979. A method for the extraction of chlorophyll from leaf tissue without maceration. Can. J. Bot. 57:1332-1334.

Kruger, E.L. and J.C. Volin. 2006. Reexamining the empirical relation between plant growth and leaf photosynthesis. Funct. Plant Biol. 33:421-429.

Kumar, S., M. Imtiyaz, A. Kumar, and R. Singh. 2007. Response of onion (Allium cepa L.) to different levels of irrigation water. Agr. Water Mgt. 89:161-166.

Leopald, A.C. 1964. Plant growth and development. McGraw-Hill, New York, NY.

Mafakheri, A., A. Siosemardeh, B. Bhramnejad, P.C. Stuik, and Y. Sohrabi. 2010. Effects of drought stress on yield, proline and chlorophyll contents in three chickpea cultivars. Australian J. Crop Sci. 4:580-585.

Mao, X., M. Liu, X. Wang, C. Liu, Z. Hou, and J. Shi. 2002. Effects of deficit irrigation on yield and water use of greenhouse grown cucumber in the north China plain. Agr. Water Mgt. 61:219-228.

Moran, J.F., M. Becan, I. Iturbe-Ormaetyl, S Frechilla, R.V. Klucas, and P. Aparicio-Tejo. 1994. Drought induces oxidative stresses in pea plants. Planta 194:346-352.

Petela, R. 2007. An approach to the energy analysis of photosynthesis. Sol. Energy 82:311-327.

Reynolds, M.P., M. van Ginkel, and J.M. Ribaut. 2000. Avenues for genetic modification of radiation use efficiency in wheat. J. Expt. Bot. 51:459-473.

Richards, R. 2000. Selectable traits to increase crop photosynthesis and yield of grain crops. J. Expt. Bot. 51:447-458

Schumann, A.W., J.P. Syvertsen, and K.T. Morgan. 2009. Implementing advanced citrus production systems in Florida: Early results. Proc. Fla. State Hort. Soc. 122:108-113.

Sezen, S.M., A. Yazar, and S. Eker. 2006. Effect of drip irrigation regimens on yield and quality of field grown bell pepper. Agr. Water Mgt. 81:115-131.

Sedibe, M.M. 2003. Optimising water using efficiency for crop production. Univ. Stellenbosch, South Africa, PhD Diss.

Silber, A., Y. Israeli, M. Levi, A. Keinan, G. Chudi, A. Golan, M. Noy, I. Levkovitch, K. Narkis, A. Naor, and S. Assouline. 2013. The role of fruit sink in the regulation of gas exchange and water uptake: A case study for avocado. Agr. Water Mgt. 116:21-28

Sing, S.K., B. Badgujar, B. Reddy, D.H. Fleisher, and J.A. Bunce. 2013. Carbon dioxide diffusion across stomata and mesophyll and photobiochemical processes as affected by growth $\mathrm{CO}_{2}$ and phosphorus nutrition in cotton. J. Plant Physiol. 170:801-813.

Vázquez, N., A. Pardo, M.L. Suso, and M. Quemada. 2006. Drainage and nitrate leaching under processing tomato growth with drip irrigation and plastic mulching. Agr. Ecosyst. Environ. 112:313-323.

Younis, M.E., O.A. El-Shahaby, S.A. Abo-Hamed, and A.H. Ibrahim. 2000. Effects of water stress on growth, pigments and $\mathrm{CO}_{2}$ assimilation in three sorghum cultivars. J. Agron. Crop Sci. 185:73-82.

Zayed, M.A. and I.M. Zeid. 1997. Effect of water and salt stresses on growth, chlorophyll, mineral ions and organic solutes contents, and enzymes activity in mung bean seedlings. Biol. Plant. 40:351-356.

Zeng, C.Z., Z.L. Bie, and B.Z. Yuan. 2009. Determination of optimum irrigation water amount for drip: Irrigated muskmelon ( $\mathrm{Cucu}$ mis melo L.) in plastic greenhouse. Agr. Water Mgt. 96:597-601 